\title{
Cloning and Characterization of the Iron Uptake Gene IutA from Avian Escherichia coli
}

\author{
Dorismey Vieira Tokano ${ }^{1 *}$, Marisa Emiko Kawaichi ${ }^{1}$, Emerson José Venâncio ${ }^{2}$ and Marilda \\ Carlos Vidotto ${ }^{1}$ \\ ${ }^{1}$ Departamento de Medicina Veterinária Preventiva; CCA; ${ }^{2}$ Departamento de Ciências Patológicas; CCB; \\ Universidade Estadual de Londrina; Campus Universitário; C. P. 6001; 86051-970; Londrina - PR - Brazil
}

\begin{abstract}
The aim of this work was to isolate, clone and characterize the iron uptake gene iutA from avian pathogenic E. coli (APEC). The iutA gene was isolated from the strain APEC 9, serotype O2:H9, which was cloned in the expression vector pET101/D-TOPO. The gene of $2.2 \mathrm{~Kb}$ was sequenced (AY602767, which showed high similarity to the iutA gene from three plasmids, two from APEC, pAPEC-02-ColV (AY545598.4) and pTJ100 (AY553855.1), and one from a human invasive E. coli strain, the pColV K30. The recombinant protein IutA was over expressed in E. coli BL21(DE-3) and was solubilized with urea and purified by Ni-NTA column. This method produced a relatively high yield of r-IutA of approximately $74 \mathrm{kDa}$, which was used to produce the antibody anti-IutA. This anti-IutA reacted with the protein r-IutA and native IutA of APEC 9, as demonstrated by Western blot, showing that the r-IutA conserved epitopes and its antigenicity was preserved. The anti-IutA IgY was able to inhibit the IutA biological activity, inhibiting the sensitivity to cloacin DF13 of APEC9. However, it did not inhibit the growth of APEC9 in M9 and did not protect the chickens inoculated with the APEC, suggesting that the APEC possessed another iron acquisition mechanism distinct of aerobactin.
\end{abstract}

Key words: Avian Escherichia coli, iron uptake, aerobactin receptor, virulence factor, iutA gene

\section{INTRODUCTION}

Escherichia coli is an important extraintestinal pathogen in the poultry, which causes significant world-wide economic losses in the production of chickens and turkeys (Gross, 1994). The avian pathogenic E. coli (APEC) strains cause colibacillosis, which usually begins by the bacterial multiplication in the upper respiratory tract, followed by the colonization of the air sacs and lungs, the bacteria then reach the blood and colonize the internal organs, causing airsacculitis, pericarditis, peritonitis and septicemia (DhoMoulin and Fairbrother, 1999, Gross, 1994). The skin lesions caused by the avian cellulitis are also commonly observed (Brito et al., 2003).
Several characteristics associated with the virulence were detected in the APEC, such as many types of adhesins and temperature-sensitive hemagglutinin (Tsh), serum resistance, iron uptake systems, hemolysins, and ColV production (Delicato et al., 2002; Delicato et al., 2003, DhoMoulin and Fairbrother, 1999; Rodriguez-Siek et al., 2005a, b; Vandekerchove et al., 2005; Vidotto et al., 1990). Some of the genes responsible for these virulence-associated factors are carried on large virulence plasmids (Ginns et al., 2000, Giddings et al., 2002; Rodriguez-Siek et al., 2005a; Schubert et al., 1998; Vidotto et al., 1990). The iron uptake mechanism more frequently found in $E$. coli is the production of siderophores, which are low molecular mass iron chelators. Several

Author for correspondence 
pathogenic bacteria with invasive abilities have developed high affinity iron-acquisition systems, which can compete with the host siderophores such as the transferrin, and thus favor bacterial growth in a low iron environment (Griffiths 1987). The APEC isolates may possess multiple iron acquisition mechanisms, including the aerobactin (Delicato et al., 2003; Dho-Moulin and Fairbrother, 1999; Vidotto et al., 1990) and yersiniabactin (Janssen et al., 2001; RodriguezSiek et al., 2005a; Vandekerchove et al., 2005). The aerobactin iron-uptake system is encoded by the genes (iuc) for the aerobactin biosynthesis, and the iron uptake transport (iut) genes responsible for the receptor of the ferric aerobactin, which is induced by the iron stress (Neilands, 1991). The role of the aerobactin iron-uptake system in the virulence of the APEC has been investigated. Studies have shown that the prevalence of the aerobactin iron-uptake genes may be more than $80 \%$ in the APEC isolates (Rodriguez-Siek et al., 2005a, Vandekerchove et al., 2005). The deletion of the aerobactin encoding gene cluster was associated with a reduction in the virulence of an APEC strain (Dozois et al., 2003)

In previous studies, the pathogenicity of the APEC has been correlated with the aerobactin ironuptake system (Brito et al., 2003; Delicato et al., 2003; Vidotto et al., 1990; Vidotto et al., 1994). The aerobactin system from a Brazilian APEC isolate was cloned and the restriction map showed similarity with the aerobactin system of pColVK30 from the human invasive E. coli (Goes et al., 1993). A 74-kDa outer-membrane protein (IutA) was also identified, with the same relative molecular mass of the IutA receptor from the pColV-K30 (Goes et al., 1993) and that crossreacted immunologically with it. The IutA protein wais a multifunctional receptor also involved in the binding and internalisation of the bacteriocin cloacin DF13 and the bacteriophage 74 (De Graaf et al., 1969; Roberts et al., 1989).

Despite the importance of the aerobactin system as a virulence factor in the extraintestinal infections, the possibility of using the aerobactin receptor (IutA protein) as a protective antigen has been little investigated (Roberts et al., 1989). Previous studies have suggested that the passive immunization with the polyclonal antibodies against the iutA protein protect the turkey and chicken from the disease caused by the APEC. In the turkeys challenged with $E$. coli, the inoculation of the rabbit antiserum against the membrane receptor of the aerobactin (IutA) significantly reduced the bacteremia and the severity of the lesions (Bolin and Jensen, 1987). In the chickens, the anti-iutA $\operatorname{IgY}$ injected intramuscularly in the broiler chickens was protective against E. coli strains (Kariyawasam et al., 2004). However, the murine monoclonal antibody to the ferric aerobactin was not efficient to protect the mice or chickens challenged with $E$. coli (Le Roy et al., 1995).

In this work, the cloning and characterization the iut A gene from a Brazilian APEC isolate was carried out and tested whether the antibodies raised against the recombinant IutA protein could inhibit the IutA biological activities.

\section{MATERIAL AND METHODS}

\section{Bacterial strain}

The avian pathogenic Escherichia coli strain APEC 9 (previously called UEL9) used in this study was recovered from the trachea of a colisepticemic chicken. This strain showed resistance to tetracycline and ampicillin, resistance to serum complement, produced colicin $\mathrm{V}$, an iron uptake system mediated by the aerobactin and carried one large plasmid of approximately 120 kilobases (Kb) (Vidotto et al., 1990). The APEC 9 strain presented serotype O2:H9:K1 (Moura et al., 2001) and was pathogenic to 1-day-old chickens by the means of the pathogenicity test, presenting $\mathrm{LD}_{50}$ of $1 \times 10^{5}$ cells/ ml. The iutA, tsh, iss, papC, papG and $c v a \mathrm{C}$ genes were detected in the E. coli APEC9 strain (Delicato et al., 2002; Delicato et al., 2003). The APEC9 also contained the gene $f y u \mathrm{~A}$ (unpublished data). The APEC 9 strain was grown overnight at $37{ }^{\circ} \mathrm{C}$ in $3 \mathrm{ml}$ of Luria Broth (LB) or M9 broth plus 2,2'dipyridyl.

\section{Cloning of iutA gene and DNA sequence analysis}

The DNA from the APEC 9 strain was obtained by boiling and used to amplify the iutA gene by the polymerase chain reaction (PCR). The primers iutA F (5'-CACCATGATGATAAGCAAAAAG3) and iut $\mathrm{A} \quad \mathrm{R}$ (5'GACCAAAGGTGGGCCCCTG CC-3`) were constructed according to the Genbank sequence (X05874). The CACC sequence from 5 end of the forward primer annealed to the overhang sequence GTGG in the pET101/D-TOPO ${ }^{\circledR}$ vector $(5,7 \mathrm{~Kb})$ (Invitrogen, Carlsbad, CA, USA). The PCR was 
carried out in a total volume of $25 \mu \mathrm{l}$ containing 5 $\mu 1$ of the DNA template, $1 \mu 1$ each of the primers at 20 pmol, $200 \mu \mathrm{M}$ of each deoxynucleoside triphosphates, $p f x$ Platinum buffer $1 \mathrm{X}, 0.5 \mu \mathrm{l}$ of 50 $\mathrm{mM}$ of magnesium sulphate, enhancer solution $0.5 \mathrm{X}$ (Invitrogen) and $2.5 \mathrm{U}$ of $P f x$ platinum DNA polymerase. The PCR conditions were as follows: denaturation at 94 for 5 min followed by 30 cycles of the denaturation at $94^{\circ} \mathrm{C}$ for $1 \mathrm{~min}$, annealing at $55^{\circ} \mathrm{C}$ for $2 \mathrm{~min}$, and extension at $72^{\circ} \mathrm{C}$ for $1 \mathrm{~min}$, followed by a final extension at $72^{\circ} \mathrm{C}$ for $7 \mathrm{~min}$ in a Thermal Cycler (Gene Amp PCR System 9700/Perkin Elmer). The 100-pb ladder (Promega, Madison, WI) was used as the standard in the determination of the molecular mass of the PCR products.

The amplification product was purified with the kit "CONCERT - System of extraction from gel" (GIBCO BRL), and 20ng of the DNA were used to insert into the pET 101/D-TOPO ${ }^{\circledR}$ vector. The host strain TOP10 chemically competent $E$. coli cells (Invitrogen) were then transformed with the recombinant plasmid and the clones were spread on the selective plates containing ampicillin. The positive clones were grown in the LB containing ampicillin for the extraction of the plasmid by the alkaline lysis (Mini Prep) (Sambrook, 1989). The presence of the iutA inserts was confirmed by the restriction digests of recombinant plasmid with $\mathrm{Xba} \mathrm{I}$ and $\mathrm{Cla} \mathrm{I}$, and by PCR. The recombinant pET101/iutA plasmid was sequenced using the primers $\mathrm{T} 3, \mathrm{~T} 7$, iutA $\mathrm{F}$, iutA $\mathrm{R}$ and internal primers. The DNA and amino acids sequence analysis were carried out with the computational programs "CAP3 Contig Assembly Program" and "Clustal W (1.81) Multiple Sequence Alignments".

\section{Expression of the iutA gene and purification of recombinant his-tagged iutA}

The E. coli BL 21 strain was transformed with the recombinant plasmid pET 101- iutA. The BL21/ pET101- iutA strain was grown to an optical density of $\mathrm{OD}_{600 \mathrm{~nm}}=0.5$ to 0.8 (mid $\log$ ), and IPTG (isopropyl-1- $\beta$ - D- thiogalactopyranoside) was then added and aliquots were removed at different times to determine the best time for the expression. The IutA purification the BL21/ pET101- iutA strain was grown at $37^{\circ} \mathrm{C}$ for $4 \mathrm{~h}$. The cells were collected by centrifugation and treated with the buffer containing $6 \mathrm{M}$ guanidine$\mathrm{HCl}$ and sonicated on the ice with three 5-second pulses at the high intensity. The lysate was then centrifuged at $3000 \mathrm{x} \mathrm{g}$ for $15 \mathrm{~min}$ and the supernatant was transferred to ProBond ${ }^{\mathrm{TM}}$ resin (Invitrogen) previously washed with the Denaturing Binding Buffer (8 M urea, $20 \mathrm{mM}$ $\mathrm{NaPO}_{4}, 500 \mathrm{mM} \mathrm{NaCl}, \mathrm{pH}$ 7.8). The supernatant and resin were incubated for $1 \mathrm{~h}$ on a rotation wheel. After centrifugation at $2000 \mathrm{rpm}$, the resin was washed two times with the Denaturing Binding Buffer at $\mathrm{pH} 7.8$, two times with the buffer at $\mathrm{pH} 6.0$, and once with the buffer at $\mathrm{pH}$ 5.3. The protein was eluted using $8 \mathrm{M}$ urea buffer at $\mathrm{pH} 4.0$, dialyzed against $10 \mathrm{mM}$ Tris $(\mathrm{pH} 8.0$; $0.1 \%$ Triton $\mathrm{X}-100$ ) overnight at $4{ }^{\circ} \mathrm{C}$ and concentrated on centrifugal microconcentrators (Centripep). The protein concentration was measured using the Bradford method and analyzed on SDS-PAGE.

\section{Analysis of IutA by the SDS PAGE and Western Blotting}

The lysates and purified protein were suspended in the electrophoresis sample buffer $(0.025 \mathrm{M}$ Tris$\mathrm{HCl}, \quad 2 \%$ SDS, $15 \%$ glycerol, $2.5 \%$ 2mercaptoethanol, $\mathrm{pH} 6.8$ ), boiled for $5 \mathrm{~min}$, and electrophoresed on the SDS-8\% polyacrylamide gel (SDS-PAGE). The gels were either stained with the Comassie blue or set up for the Western blot. The proteins were transferred onto nitrocellulose membranes (Pharmacia Biotech) and the membranes were blocked with the blocking buffer (PBS $+0.1 \%$ Tween $20+5 \%$ nonfat dry milk) for $1 \mathrm{~h}$ at room temperature under agitation. The membrane was washed in PBS-T (PBS $+0.1 \%$ Tween 20) and incubated for $1 \mathrm{~h}$ in a 1:5000 dilution of Anti-His (C-term)-HRP (Invitrogen) directed against the hexamer histidine tag, and in a 1:250 dilution of IgY anti IutA and HRP anti-chicken IgG (Sigma Immuno Chemicals). The membranes were washed and the recombinant IutA was detected by the means of the enhanced chemoluminescence (ECL) Western Blotting System (Amersham International, Amersham, United Kindom). The protein molecular weight markers (Rainbow ${ }^{\mathrm{TM}}$ colored, Amersham Life Science) were used as the standards.

\section{Anti-IutA antibody production}

For the antibody production, the recombinant IutA protein (approximately 100 $\mu \mathrm{g}$ ) was cut from the SDS-PAGE gel and intramuscularly inoculated with the complete Freund's adjuvant (v/v) into the 
hens. The animals were boosted with the injections containing $100 \mu \mathrm{g}$ of the antigen mixed with incomplete Freund's adjuvant (v/v) at 2 weeks and 4 weeks after the initial immunization. The eggs were collected prior to the first inoculation and daily during the course of the immunization. The eggs were stored at $4^{\circ} \mathrm{C}$ until the antibody extraction. IgY from the yolk was isolated as described by Camenisch et al. (1999). The IgY antibodies were adsorbed with the BL21 E. coli strain that was negative for $i u t \mathrm{~A}$, to prepare the specific anti-iutA IgY. The BL21 E. coli cells grown in the LB broth were washed three times in the PBS and inactivated with $0.4 \%$ formalin overnight. After washes with the PBS, the cells were added to same volume of the anti-iutA IgY and incubated overnight with shaking, and repeated three times. After the centrifugation, the concentration of the anti-iutA IgY was measured by the Bradford method (1976).

\section{Growth curve of the APEC9 incubated with} and without anti-iutA IgY

The APEC9 strain was grown in M9 broth plus 50 $\mu \mathrm{M} 2,2^{\prime}$ 'dipyridyl at $37^{\circ} \mathrm{C}$. Thirty millilitres of the prepared bacterial culture were inoculated in $3 \mathrm{ml}$ of M9 broth plus 2,2'dipyridyl and incubated at $37^{\circ} \mathrm{C}$ with shaking. The anti-iutA IgY preparation was sterilized by using a $22 \mu \mathrm{m}$ membrane filter. The APEC9 strain was incubated with $3 \mathrm{mg}$ of $\mathrm{IgY}$ in M9 broth plus $50 \mu \mathrm{M} 2,2^{\prime}$ dipyridyl at $37^{\circ} \mathrm{C}$ with shaking. Aliquots of samples $(100 \mu \mathrm{l})$ were taken at $0,2,4,6$ and $8 \mathrm{~h}$ of incubation and spread on LB agar plates in duplicate. The inoculated plates were incubated at $37^{\circ} \mathrm{C}$ overnight and the number of colony-forming units per $\mathrm{ml}$ was determined. The growth curve of the APEC9 strain was obtained in $\mathrm{LB}$ at $37^{\circ} \mathrm{C}$, with and without Ig Y. The turbidity of the culture (optical density at $600 \mathrm{~nm}$ ) was measured by a spectrophotometer at $1 \mathrm{~h}$ intervals. The growth curve was plotted until the stationary phase was reached.

\section{Cloacin DF13 extraction}

The DF13 cloacin was produced as described by De Graaf et al. (1968). Mitomicin C (Sigma) 1 $\mathrm{ug} / \mathrm{ml}$ was added to $E$. coli F205 exponential culture in the BHI, and incubated for $10 \mathrm{~min}$. at $37^{\circ} \mathrm{C}$. After centrifugation, the cells were suspended in the BHI and incubated for $3 \mathrm{~h}$ at $37^{\circ} \mathrm{C}$. Ammonium sulphate was added to the culture supernatant for the precipitation of the cloacin, which was dialyzed, sterilized by filtration and kept at $-20^{\circ} \mathrm{C}$.

\section{Sensitivity to cloacin test and its inhibition by the anti-IutA IgY}

Initially the APEC9 strain was grown at $37^{\circ} \mathrm{C}$ in M9 broth plus 2,2' dipyridyl, and plated onto M9 agar plus 2,2'dipyridyl. This strain was also incubated with IgY anti-IutA for $1 \mathrm{~h}$ prior to the plating onto M9 agar plus 2,2'dipyridyl. A crude preparation of the cloacin DF13 $(20 \mu \mathrm{l})$ was deposited on each plate and then incubated for 18 $\mathrm{h}$ at $37^{\circ} \mathrm{C}$. A zone of growth inhibition indicated that the strain was sensitive to cloacin, and the absence of this zone indicated that the strain was resistant to cloacin. The E. coli LG1315 and HB101 strains were used as the positive and negative controls, respectively.

\section{Experimental infection of the chicks}

Four groups of one-day-old chicks $(n=6)$ were subcutaneously infected with the APEC 9 strain (1 x $10^{7}$ cells). The strain was grown at $37^{\circ} \mathrm{C}$ in $\mathrm{M} 9$ broth plus 2,2'dipyridyl, and after wash with the PBS the APEC9 was incubated with $0.1 \mathrm{mg}$ of antiIutA IgY (group I), $1 \mathrm{mg}$ of anti-IutA $\operatorname{IgY}$ (group II), and the PBS (group III) for $1 \mathrm{~h}$ at $37^{\circ} \mathrm{C}$ before the experimental infection. As negative control group IV was inoculated with the PBS. The chickens were monitored for the mortality during one week. The clinical signs and deaths were recorded daily.

\section{RESULTS}

Cloning of the iutA gene and its DNA sequence The iutA gene from the APEC9 was amplified by the PCR. A DNA fragment of approximately 2.1 $\mathrm{Kb}$ was obtained, purified and cloned into the expression vector pET101/D-TOPO. The recombinant plasmid pET101-iutA was analysed by the digestion with $X b a \mathrm{I}$ and $C l a \mathrm{I}$. The $X b a \mathrm{I}$ digestion resulted in a DNA fragment of $7.9 \mathrm{~Kb}$, corresponding to $5.7 \mathrm{~Kb}$ of the vector plus $2.1 \mathrm{~Kb}$ of the insert. The ClaI digestion produced two DNA fragments with 6.0 and $1.8 \mathrm{~Kb}$, showing that the iutA gene was inserted in the desired reading frame into $\mathrm{pET} 101 / \mathrm{D}-\mathrm{TOPO}$ vector. 
AAT 35536 AAS 66997 ABA 54744 CAA2 9297 CAE 55774 AAN82071 AAT 35536 AAS 66997 ABA 54744 CAA2 9297 CAE 55774 AAN82071

AAT 35536 AAS 66997 ABA 54744 CAA2 9297 CAE 55774 AAN82071

AAT 35536 AAS 66997 ABA 54744 CAA2 9297 CAE 55774 AAN82071

AAT 35536 AAS 66997 ABA 54744 CAA2 9297 CAE 55774 AAN82071 AAT 35536 AAS 66997 ABA 54744 CAA2 9297 CAE 55774 AAN82071

AAT35536 AAS 66997 ABA 54744 CAA2 9297 CAE 55774 AAN82071

AAT35536 AAS 66997 ABA 54744 CAA2 9297 CAE 55774 AAN82071

AAT 35536 AAS 66997 ABA 54744 CAE 55774 CAA2 9297 AAN82071 AAT 35536 AAS 66997 ABA 54744 CAA2 9297 CAE 55774 AAN82071

AAT35536 AAS 66997 ABA 54744 CAA2 9297 CAE 55774 AAN 82071

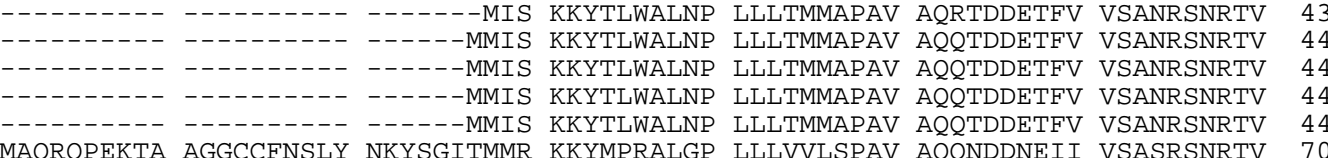
MAQRQPEKTA AGGCCFNSLY NKYSGITMMR KKYMPRALGP LLLVVLSPAV AQQNDDNEII VSASRSNRTV 70 AEMAQTTWVI ENAELEQQIQ GGKELKDALA QLIPGLDVSS RSRTNYGMNV RGRPLVVLVD GVRLNSSRTD 113 AEMAQTTWVI ENAELEQQIQ GGKELKDALA QLIPGLDVSS RSRTNYGMNV RGRPLVVLVD GVRLNSSRTD 114 AEMAOTTWVI ENAELEOQIO GGKELKDALA OLIPGLDVSS RSRTNYGMNV RGRPLVVLVD GVRLNSSRTD 114 AEMAQTTWVI ENAELEQQIQ GGKELKDALA QLIPGLDVSS RSRTNYGMNV RGRPLVVLVD GVRLNSSRTD 114 AEMAQTTWVI ENAELEQQIQ GGKELKDALA QLIPGLDVSS RSRTNYGMNV RGRPLVVLVD GVRLNSSRTD 114 AEMAQTTWVI ENAELEQQIQ GGKELKDALA QLIPGLDVSS QSRTNYGMNM RGRPLVVLID GVRLNSSRSD 140 SRQLDSIDPF NIDHIEVISG ATSLYGGGST GGLINIVSKK GQPETMKEFE AGTKSGFSSS KDHDERIAGA 183 SRQLDSIDPF NIDHIEVISG ATSLYGGGST GGLINIVTKK GQPETMMEFE AGTKSGFSSS KDHDERIAGA 184 SRQLDSIDPF NIDHIEVISG ATSLYGGGST GGLINIVTKK GQPETMMEFE AGTKSGFSSS KDHDERIAGA 184 SROLDSIDPF NMHHIEVIFG ATSLYGGGST GGIINIVTKK GOPETMMEFE AGTKSGFSSS KDHDERIAGA 184 SRQLDSIDPF NIDHIEVISG ATSLYGGGST GGLINIVTKK GQPETMMEFE AGTKSGFSSS KDHDERIAGA 184 SRQLDSVDPF NIDHIEVISG ATALYGGGST GGLINIVTKK GQPETMMEFE AGTKSGFNSS KDHDERIAGA 210 VSGGNEHISG RLSVAYQKFG GWFDGNGDAT LLDNTQTGLQ YSDRLDIMGT GTLNIDESRQ LQLITQYYKS 253 VSGGNEHISG RLSVAYQKFG GWFDGNGDAT LLDNTQTGLQ YSDRLDIMGT GTLNIDESRQ LQLITQYYKS 254 VSGGNEHISG RLSVAYQKFG GWEDGNGDAT LLDNTQTGLQ YSDRLDIMGT GTLNIDESRQ LQLITQYYKS 254 VSGGNEHISG RLSVAYQKFG GWFDGNGDAT LLDNTQTGLQ YSDRLDIMGT GTLNIDESRQ LQLITQYYKS 254 VSGGNEHISG RLSVAYQKFG GWFDGNGDAT LLDNTQTGLQ YSDRLDIMGT GTLNIDESRO LOLITQYYKS 254 VSGGNDHISG RLSVAYQKFG GWFDGNGDAT LLDNTQTGLQ HSNRLDIMGT GTLNIDESRQ LQLITQYYKS 280 QGDDDYGLNL GKGFSAIRGT STPFVSNGLN SDRIPGTERH LISLQYSDSA FLGQELVGQV YYRDESLRFY 323 QGDDDYGLNL GKGFSAIRGT STPFVSNGLN SDRIPGTERH LISLOYSDSA FLGOELVGOV YYRDESLRFY 324 QGDDDYGLNL GKGFSAIRGT STPFVSNGLN SDRIPGTERH LISLQYSDSA FLGQELVGQV YYRDESLRFY 324 QGDDDYGLNL GKGFSAIRGT STPFVSNGLN SDRIPGTDGH LISLQYSDSA FLGQELVGQV YYRDESLRFY 324 QGDDDYGLNL GKGFSAIRGT STPFVSNGLN SDRIPGTERH LISLQYSDSA FLGQELVGQV YYRDESLRFY 324 QGDDNYGLNL GKGFSAISGS STPYVSKGLN SDRIPGTERH LISLQYSDSD FLRQELVGQV YYRDESLRFY 350 PFPTVNANKQ VTAFSSSQQD TDQYGMKLTL NSKPMDGWQI TWGLDADHER FTSNQMFFDL AQASASGGLN 393 PFPTVNANKQ VTAFSSSQQD TDQYGMKLTL NSKPMDGWQI PWGLDADHER FTSNQMFFDL AQASASGGLN 394 PFPTVNANKO VTAFSSSOOD TDOYGMKLTL NSKPMDGWOI TWGLDADHER FTSNOMFFDL AOASASGGLN 394 PFPTVNANKQ VTAFSSSQQD TDQYGMKLTL NSKPMDGWQI TWGLDADHER FTSNQMFFDL AQASASGGLN 394 PFPTVNANKQ VTAFSSSQQD TDQYGMKLTL NSKPMDGWQI TWGLDADHER FTSNQMFFDL AQASASGGLN 394 PFPTVNANKQ ATAFSSSQQD TDQYGMKLTL NSQLMDGWQI TWGLDAEHER FTSNQMFFDL AQASASGGLN 420 NKKIYTTGRY PSYDITNLAV FLQSGYDINN LFTLNGGVRY QYTENKIDDF IGYAQQRQIA AGKAISADAI 463 NKKIYTTGRY PSYDITNLAA FLQSGYDINN LFTLNGGVRY QYTENKIDDF IGYAQQRQIA AGKATSADAL 464 NKKIYTTGRY PSYDITNLAA FLQSGYDINN LFTLNGGVRY QYTENKIDDF IGYAQQRQIA AGKATSADAI 464 NKKIYTTGRY PSYDITNLAA FLOSGYDINN IFTLNGGVRY OYTENKIDDF IGYAOOROIG AGKATSADAF 464 NKKIYTTGRY PSYDITNLAA FLQSDYDINN LFTLNGGVRY QYTENKIDDF IGYAQQRQIA AGKATSADAI 464 NHKIYTTGRY PSYDITNLAA FLQSSYDIND IFTVSGGVRY QYTENRVDDF IDYTQQQKIA AGKAISADAI 490 PGGSVDYDNF LFNAGLLMHI TERQQAWLNF SQGVELPDPG KYYGRGIYGA AVNGHLPLTK SVNVSDSKLE 533

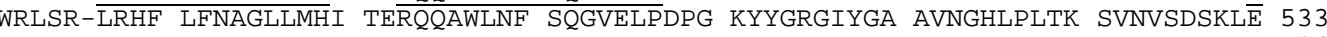
PGGSVDYDNF LFNAGLLMHI TERQQAWLNF SQGVELPDPG KYYGRGIYGA AVNGHLPLTK SVNVSDSKLE 534 WRLSR-LRHF LFNAGLLMHI TEPQQAWLNF SQGLELPDPG KYYGRGIYGA AVNGHLPLTK SVNVSDSKLE 533 PGGSVDYDNF LFNAGLLMHI TEROOAWLNF SOGVELPDPG KYYGRGIYGA AVNGHLPLTK SVNVSDSKLE 534 PGGSVDYDNF LFNAGLLMHI TERQQAWFNF SQGVALPDPG KYYGRGIYGA AVNGHLPLTK SVNVSDSKLE 560 GVKVDSYELG WRFTGNNLRT QIAAYYSISD KSVVANKDLT ISVVDDKRRI YGVEGAVDYL IPDTDWSTGV 603 GVKVDSYEIG WRETGNNL RT OIAAYYSISD KSVVANKDLT ISVVDDKRRI YGVEGAVDYL IPDTDWSTGV 603 GVKVDSYELG WRFTGNNLRT QIAAYYSISD KSVVANKDLT ISVVDDKRRI YGVEGAVDYL IPDTDWSTGV 604 GVKVDSYELG WRFTGNNLRT QIAAYYSISD KSVVANKDLT ISVVDDKRRI YGVEGAVDYL IPDTDWSTGV 604 GVKVDSYELG WRFTGNNLRT QIAAYYSISD KSVVANKDLT ISVVDDKRRI YGVEGAVDYL IPDTDWSTGV 603 GVKVDSYELG WRFTGDNLRT QIAAYYSLSN KSVERNKDLT ISVKDDRRRI YGVEGAVDYL IPDTDWSTGV 640 NFNVLKTESK VNGTWQKYDV KTASPSKATV YIGWAPDPWS LRVQSTTSFD VSDAQGYKVD GYTIVDLLGS 673 NFNVLKTESK VNGTWQKYDV KTASPSKATA YIGWAPDPWS LRVQSTTSFD VSDAQGYKVD GYTTVDLLGS 673 NFNVLKTESK VNGTWOKYDV KTASPSKATA YIGWAPDPWS LRVOSTTSFD VSDAOGYKVD GYTTVDLLGS 674 NFNVLKTESK VNGTWQKYDV KTASPSKATA YIGWAPDPWS LRVQSTTSFD VSDAQGYKVD GYTTVDLLGS 673 NFNVLKTESK VNGTWQKYDV KTASPSKATA YIGWAPDPWS LRVQSTTSFD VSDAQGYKVD GYTTVDLLGS 674 NFNVLKTESK VNGQWQKYDV KESSPSKATA YINWAPEPWS LRVQSTTSFD VSDAEGNDIN GYTTVDFISS 710 YQLPVGTLSF SIENLFDRDY TTVWGQRAPL YYSPGYGPAS LYGDKGRGPP LV------- 725 YQLPVGTLSF SIENLFDRDY TTVWGQRAPL YYSPGYGPAS LYDYKGRGRT FGLNYSVLF 732 YQLPVGTLSF SIENLFDRDY TTVWGQRAPL YYSPGYGPAS LYDYKGRGRT FGLNYSVLF 733 YOLPVGTLSF SIENLFDRDY TTVWGORAPL YYSPGYGPAS IYDYKGRGRT FGLNYSVLF 732 YQLPVGTLSF SIENLFDRDY TTVWGQRAPL YYSPGYGPAS LYDYKGRGRT FGLNYSVLF 733 WQLPVGTLSF SVENLFDRDY TTVWGQRAPL YYSPGYGPAS LYDYKGRGRT FGLNYSVLF 759

Figure 1 - Multiple sequence alignment of iutA protein from E. coli. The figure compares amino acid sequences from APEC9 (AAT35536), APEC pTJ100 plasmid (AAS66997), APEC ColVO2 plasmid (ABA54744), ColV-K30 plasmid (CAA29297), non pathogenic E.coli (CAE55774), and uropathogenic E. coli (AAN82071). Conserved amino acid residues in putative TonB dependent/Ligand-Gated channel domain from APEC9 are underlined

Braz. arch. biol. technol. v.51 n.3: pp.473-482, May/June 2008 4 4 . 
The ORF from of cloned iutA gene from the avian E. coli APEC9 comprised 2173 bp from the start to stop codon (Genebank AY602767). The databank searches for the similar nucleotide sequence showed that the APEC9 iutA gene had 98 and $97 \%$ identity with the plasmid genes from other APEC, pAPEC-02-ColV (AY545598.4) and pTJ100 (AY553855.1), respectively. Moreover, the APEC9 iutA gene showed $96 \%$ identity with the iutA gene from the pColV-K30 of the human E. coli (Krone et al.,1987) and $88 \%$ with uropathogenic E. coli CFT073 (Welch et al., 2002). The IutA protein cloned from the APEC9 showed high similarity to other receptors of the ferric aerobactin from E. coli. Fig. 1 compares the amino acid sequences of IutA protein from APEC9 (AAT35536), APEC pTJ100 plasmid (AAS66997), APEC ColV-O2 plasmid (ABA54744), ColV-K30 plasmid (CAA29297), non pathogenic E.coli (CAE55774), and uropathogenic E. coli (AAN82071). Conserved amino acid residues in the putative TonB dependent/Ligand-Gated channel domain from APEC9 are underlined.

\section{Expression and purification of the recombinant IutA protein in $E$. coli BL21}

The IutA protein was better induced after the incubation of $E$. coli BL21/pET101-iutA, with 1 $\mathrm{mM}$ of IPTG for $4 \mathrm{~h}$. The profile of the proteins on the SDS-PAGE showed the presence of the induced IutA (Fig. 2A, line 2) in comparison with the clone BL21/pET101-iutA with no induction (Fig. 2A, line 1). The "his-tagged" IutA protein was purified from ProBond ${ }^{\mathrm{TM}}$ resin under denaturing conditions, presenting a $\mathrm{MM}$ of approximately $74 \mathrm{kDa}$ (Fig.2A, line 3), which reacted with the anti-his monoclonal antibody on the Western blot (data not shown). A protein of approximately $50 \mathrm{kDa}$ present on the SDS-PAGE stained with Comassie blue was probably a contaminating protein since it did not react with anti-IutA IgY, which was adsorbed with the BL21 E. coli strain. The clone BL21/ pET101-iutA was resistant to cloacin, since the recombinant IutA was not present on its outer membrane. The reactivity of the recombinant IutA with the antiIutA IgY on the Western blot shown in the Fig.2B (lines 2 and 3), and nonimmune $\operatorname{IgY}$ at the same dilution, did not react with IutA.

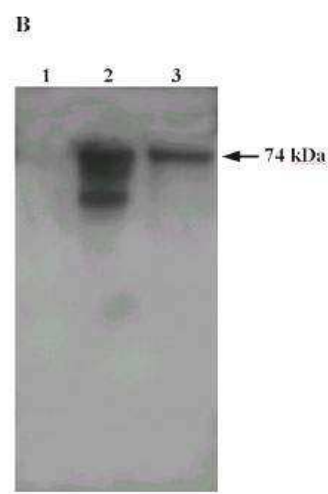

Figure 2 - Expression and purification of $74 \mathrm{kDa}$ protein by clone E. coli/pET101-iutA. A. SDSPAGE $12 \%$ stained with Comassie brilhant blue. B. Western blot of rIutA with IgY anti-IutA. Lane 1, clone BL21/pET101- iutA no induced; 2, clone induced with IPTG $1 \mathrm{mM} ; 3$, eluted rIutA

\section{Effect of the antibodies anti-IutA IgY on IutA biological activities}

The growth curves of the APEC9 incubated with and without anti-iutA IgY showed similar pattern (Fig. 3), indicating that this specific IgY had no growth-inhibitory effect on the APEC9 strain when it was induced after growth in M9 broth plus $50 \mu \mathrm{M} 2,2$ ' dipyridyl (iron stress).

The APEC9 strain, which was sensitive to cloacin due to the presence of IutA protein, showed resistance to cloacin after incubation with the antiIutA IgY (Fig. 4), demonstrating the inhibition of 
the IutA biological activities by the specific antibody. The sensitivity to cloacin DF13 assay was used because it was a good in vitro assay for checking the presence of the native IutA protein, since IutA was also a cloacin receptor and cloacin inhibited the growth of E. coli.

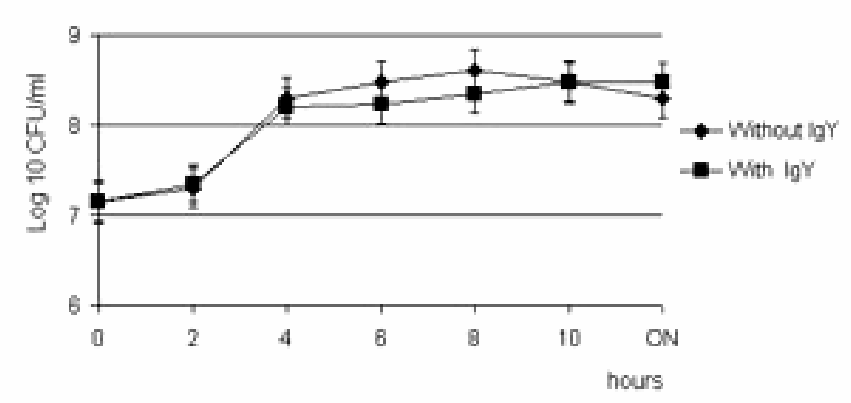

Figure 3 - Growth curve of APEC9 incubated with and without anti-iutA IgY

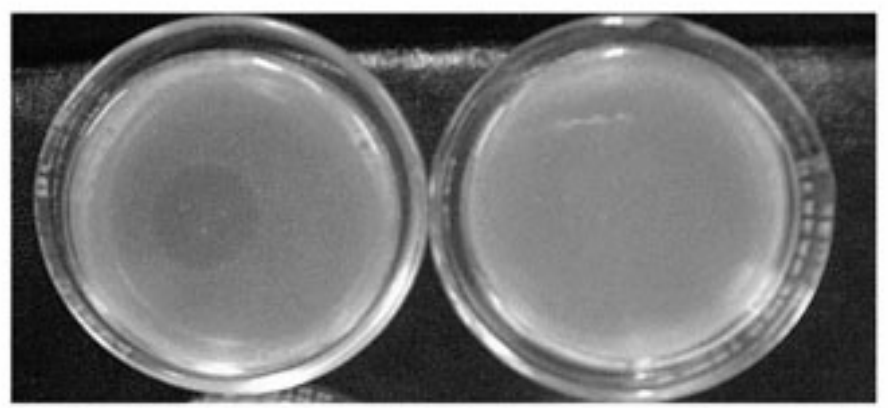

A

B

Figure 4 - Inhibition of IutA biological activities by IgY anti-IutA. A. APEC9 sensitive to cloacin.

B. APEC9 incubated with anti- IutA, indicating resistance to cloacin

In in vivo experiments, the anti-IutA $\operatorname{IgY}$ did not protect the chicks of the experimental infection by the subcutaneous inoculation of the APEC9 strain in one-day-old chicks. All the six chicks died (100\%), when infected with the APEC9 and the APEC treated with the anti-IutA IgY (groups I and II) or the PBS (group III), whereas all the chicks from the non-inoculated group (IV) survived.

\section{DISCUSSION}

The iutA gene of the pMV14 from the APEC14 expressed an OMP of approximately $74 \mathrm{kDa}$, the ferric-aerobactin receptor (Goes et al., 1993), which showed homology with the IutA protein of
pABN1 from the human pathogenic E. coli strain (Williams, 1979), by restriction endonuclease mapping and hybridisation experiments. In this work, the sequence of the iutA gene cloned from another Brazilian avian E. coli (APEC9) presented high identity $(98,97$ and 96\%) with the iutA genes previously characterised from the pColV- 02 and pTJ100 plasmids of APEC, and from the pColV$\mathrm{K} 30$ of the human invasive $E$. coli strain, demonstrating that the IutA protein was highly conserved among the E. coli strains.

The IutA amino acid sequence of the APEC9 presented some differences to those of the uropathogenic E. coli CFT073 (AAN82071), but the amino acid residues in the TonB dependent/Ligand-Gated channel domain, 
underlined in Fig. 1, were highly conserved. The product of the TonB gene was necessary for the uptake of the iron by all the high-affinity irontransport systems (Neilands, 1991).

It was observed that the antibodies $\operatorname{IgY}$ anti-iutA reacted with the denatured IutA proteins as shown by the Western blot (Fig 2B) and also reacted with the native IutA, inhibiting the sensitivity to cloacin of the APEC9 strain. This data agreed with the results obtained with the monoclonal antibody AB9 produced against the denatured IutA from the pColV K30 that also reacted with the native IutA of different enteric bacteria (Bouchet et al., 1994). In contrast, the antisera raised in the rabbits against the denatured IutA reacted only in the assays involving the denatured protein, and showed no inhibition of the biological activities of the native receptor (Welch et al., 2002).

Although the anti-IutA IgY reacted with the aerobactin receptor, it did not inhibit the growth of the APEC9 strain in M9 broth plus $50 \mu \mathrm{M}$ 2,2'dipyridyl, suggesting that APEC9 had means other than through the expression of the aerobactin to obtain the iron under low iron conditions. For example, the irp2-fyuA gene cluster, encoding the iron chelator yersiniabactin, has been found in $E$. coli isolated from the humans (Gophna et al., 2001, Schubert et al., 1998) and birds (Janssen et al., 2001, Rodriguez-Siek et al., 2005a, Vandekerchove et al., 2005). Furthermore, the presence of the fyuA was detected in the APEC9.

In addition, results showed that the anti-iutA IgY did not protect the chicks experimentally infected with the APEC9. This result was in disagreement with the findings obtained in the previous studies (Bolin and Jensen, 1987, Kariyawasam et al., 2004) and could be explained by the presence of the multiple iron acquisition mechanisms in the APEC9 and the presence of both the iutA and fyuA genes has been detected in $90 \%$ of the E. coli strains isolated from the hens with the colibacillosis (Rodriguez-Siek et al., 2005b). It was also possible that in the present in vivo protocol low doses of IgY anti-iutA $(0.1$ and $1 \mathrm{mg}$ of $\mathrm{IgY}$ ) were administrated. In the previous studies, the doses as high as $100 \mathrm{mg}$ of the purified IgY anti-iutA antibody or the rabbit antiserum specific to iutA protein diluted or undiluted protected chicken and turkeys from the E. coli septicemia, respectively (Kariyawasam et al., 2004). These observations suggested that the antibody specific to the iutA protein might provide the protection against infection by APEC.
In conclusion, the iut $\mathrm{A}$ gene from the Brazilian APEC strain showed high similarity to the iutA gene from others APEC strains and from a human invasive $E$. coli strain. The recombinant IutA protein induced the production of the antibodies in the chickens, which inhibited the aerobactin receptor biological activity.

\section{ACKNOWLEDGMENTS}

The authors wish to thank Prof. L.C.J. Gaziri for help in revising the manuscript. This work was supported by the "Conselho Nacional de Desenvolvimento Científico e Tecnológico" (CNPq).

\section{RESUMO}

A proteína de membrane externa IutA (iron uptake transport) é o receptor para aerobactina férrica, um fator de virulência encontrado mais frequentemente entre as amostras de E. coli pathogênicas para aves (APEC) do que entre os isolados fecais de aves saudáveis. O gene iutA da amostra APEC 9, sorotipo O2:H9, foi amplificado e clonado no vetor pET101/D-TOPO. O gene iutA $2.2 \mathrm{~Kb}$ foi sequenciado (AY602767) e mostrou alta similaridade para gene iutA de três plasmidios, dois da APEC, pAPEC-02-ColV (AY545598.4) e pTJ100 (AY553855.1), e um da amostra E. coli invasiva humana, pColV K30. A proteína IutA recombinante (r-IutA) foi produzida em Escherichia coli BL21(DE-3), solubilizada com uréia e purificada em coluna de níquel Ni-NTA. A r-IutA tem aproximadamente $74 \mathrm{kDa}$ e foi utilizada para produzir anticorpos anti-IutA. Este anticorpo reagiu com a $\mathrm{r}$ - IutA e com IutA da APEC13, como demonstrado por

Western blot, mostrando que a r-IutA tem epitopos conservados e sua antigenicidade foi preservada. $\mathrm{O}$ anticorpo anti-IutA foi capaz de inibir a atividade biológica da IutA, inibindo o teste positivo de sensibilidade à cloacina DF13 apresentada pela APEC 9, contudo não inibiu o crescimento da APEC9 crescida em M9 e não protegeu os pintinhos inoculados com APEC 9, sugerindo que a APEC possui outro mecanismo de captação de íons ferro distinto da aerobactina. 


\section{REFERENCES}

Bolin, C.A. and Jensen, A. B. (1987), Passive Imunization with antibodies against iron-regulated outer membrane proteins protect turkeys from Escherichia coli septicemia. Infection and Immunity. 55, 1239-1242.

Bouchet, A.; Valvano, A. M.; Dho-Moulin M.; Le Roy, D. and Andremot, A. (1994), Immunological Variants of the Aerobactin-Cloacin DF13 Outer Membrane Protein Receptor IutA among Enteric Bacteria. Infection and Immunity. 62, 3017-3021.

Brito, B. G.; Gaziri, L. C. J. and Vidotto M. C. (2003), Virulence factors and clonal relationships among Escherichia coli strains isolated from broiler chickens with cellulites. Infect. Immun. 71, 4175-4177.

Camenisch, G., Tini, M.; Chilov, D.; Kvietikova, I; Srinivas, V.; Caro, J.; Spielmann,P.; Wenger, R. H.; Gassmann M. (1999), General applicability of chicken egg yolk antibodies: the performance of $\operatorname{IgY}$ immunoglobulins raised against the hypoxiainducible factor 1 alfa. FASEB J. 13, 81-88.

Delicato, E. R.; Brito, B.G.; Konopatzki, A. P.; Gaziri, L. C. J. and Vidotto M. C. (2002), Occurrence of the temperature-sensitive hemagglutinin among avian Escherichia coli. Avian Dis. 46, 713-716.

Delicato, E. R.; Brito, B. G.; Gaziri L. C. J. and Vidotto M. C. (2003), Virulence associated genes in Escherichia coli isolates from poultry with colibacillosis. Vet. Microbiol. 94, 97-103.

De Graaf, F. K.; Spanjaerdt - Speckman, E. A. and Stouthamer A. H. (1969), Mode of Action of a bacteriocin produced by Enterobacter cloaceae DF 13. J. Microbiol. Serol. 35, 287-306.

Dho-Moulin, M. and Fairbrother J. M. (1999), Avian pathogenic Escherichia coli (APEC). Review. Vet. Res. 30, 299-316.

Dozois, C.M.; Daigle, F. and Curtiss III, R. (2003), Identification of pathogen-specific and conserved genes expressed in vivo by an avian pathogenic Escherichia coli strain. PNAS. 100, 247-252.

Ginns, C. A.; Benham, M. L.; Adams, L. M.; Whithear, K.G.; Bettelheim K. A.; Crabb, B. S. and Browning G. F. (2000), Colonization of the respiratory tract by a virulent strain of avian Escherichia coli requires carriage of a conjugative plasmid. Infect Immun. 68, 1535-41.

Goes, C.R.; Vidotto, M. C. and Gaziri. L. C. J. (1993), Cloned genes of the aerobactin system of virulent avian Escherichia coli do not confer virulence to recombinant strains. Braz. J. Med Biol.Res. 26, 261275.

Gophna, U.; Oelschlaeger, T. A.; Hacker, J. and Ron, E.Z. (2001), Yersinia HPI in septicemic Escherichia coli strains isolated from diverse hosts. FEMS Microbiol. Letters 196, 57-60.
Griffiths, E. (1987), The iron-uptake system of pathogenic bacteria. In: Iron and infection: molecular physiological and clinical aspects, Ed. By J.J. Bullen, E.Griffiths. Chichester: England. pp. 69-137.

Gross, W.B. (1994), Diseases due to Escherichia coli in poultry. In: Gyles, C.L.(Ed.), Escherichia coli in Domestic Animals and Humans, CAB International,UK, Wallingford, pp.237-259.

Janssen, T.; Schwarz, C.; Preikschat, P.; Voss, M.; Phillip, H. and Wieler, L. H. (2001), Virulenceassociated genes in avian pathogenic Escherichia coli (APEC) isolated from internal organs of poultry having died from colibacillosis. Int. J. Med. Microbiol. 291, 371-378.

Giddings, C.W.; Horne, S. M.; Gibbs, P. S.; Wooley, R. E.; Skyberg, J.; Olah, P.; Kercher, R.; Sherwood, J. S.; Foley S. L. and Nolan, L. K. (2002), Location of increased serum survival gene and selected virulence traits on a conjugative $\mathrm{R}$ plasmid in an avian Escherichia coli isolate. Avian Dis. 46, 342-352.

Kariyawasam, S.; Wilkie, B. N. and Gyles C. L. (2004), Resistance of broiler chickens to Escherichia coli respiratory tract infection induced by passively transferred egg-yolk antibodies. Veterinary Microbiology 98, 273-284.

Krone, W. J. A.; Stegehuis, F.; Koningstein, G.; van Doorn, C.; Roosendaal, B.; de Graaf, F.K. and Oudega, B. (1987), Characterization of the pColVK30 encoded cloacin DF13/aerobactin outer membrane receptor protein of Escherichia coli; isolation and purification of the protein and analysis of its nucleotide sequence and primary structure. FEMS Microbiol. Lett. 26, 153-161.

Le Roy, D., C. Crouzier, M. Dho-Moulin, A. S. Dumont, A. Bouchet, J. P. Lafont, A. Andremont.(1995), Results of passive and active immunization directed against ferric aerobactin in experimental enterobacterial infections in mice and chickens. Res Microbiol. 146: 167-74.

Neilands, J.B. (1991), Mechanism and regulation of syntesis of aerobactin in E. coli K12 (pColV-K30). Can. J. Microbiol. 38: 728-733.

Moura, A.C., K. Irino, M. C. Vidotto. (2001), Genetic Variability of avian Escherichia coli strains evaluated by enterobacterial repetitive intergenic consensus and repetitive extragenic palindromic polymerase chain reaction. Avian Dis. 45: 173-181.

Roberts, M. K., H. G. Woolridge, S. I. Kuswandi, P. H. Williams. (1989), Inhibition of biological activities of the aerobactin receptor protein in rough strains of Escherichia coli by policlonal antiserum raised against native protein. J. Gen. Microbiol. 135: 23872398.

Rodriguez-Siek, K.E., C. W. Giddings, C. Doetkott, T. J. Johnson, L. K. Nolan. (2005a), Characterizing the APEC pathotype. Vet Res. 36: 241-56. 
Rodriguez-Siek, K. E., C. W. Giddings, C. Doetkott, T. J. Johnson, M. K. Fakhr, L. K. Nolan. (2005b), Comparison of Escherichia coli isolates implicated in human urinary tract infection and avian colibacillosis. Microbiology. 151:2097-110.

Sambrook, J., E. F. Fritsch, T. Maniatis. (1989), Molecular cloning: a laboratory manual, $2^{\text {nd }}$ ed. Cold Sring Harbor Laboratory Press, Cold Spring Harbor, N.Y.

Schubert, S., A. Rakin, H. Karch, E. Carniel, J. Heesemann. (1998), Prevalence of the "highpathogenicity island" of Yersinia species among Escherichia coli strains that are pathogenic to humans. Infect. Immun. 66: 480-485.

Tivendale, K. A., J. L. Allen, C. A. Ginns, B. S. Crabb, G. F. (2004), Browning. Association of iss and iucA, but not tsh, with plasmid-mediated virulence of avian pathogenic Escherichia coli. Infect. Immun. 72: 5460.

Vandekerchove, D., F. Vandemaele, C. Adriaensen, M. Zaleska, J. P. Hernalsteens, L. De Baets, P. Butaye, F. Van Immerseel, P. Wattiau, H. Laevens, J. Mast, B. Goddeeris, F. Pasmans. (2005), Virulence-associated traits in avian Escherichia coli: Comparison between isolates from colibacillosis-affected and clinically healthy layer flocks. Vet. Microbiol. 108: 75-87.
Vidotto, M. C., E. E. Muller, J. C. Freitas, A. A. Alfieri, I. G. Guimarães, D.S. Santos. (1990), Virulence factors of avian Escherichia coli. Avian Dis. 34: 531-538.

Vidotto, M.C., V. A. Terra, G. S. C. C. Lima, A. F. Alfieri, C. R. Goes, J. M. C. Cação. (1994), Ironregulated outer-membrane proteins of strains of avian septicemic Escherichia coli. Braz. Med. Biol. Res. 27: 1291-1297.

Welch R. A., V. Burland, G. Plunkett 3rd, P. Redford, P. Roesch, D. Rasko, E. L. Buckles, S. R. Liou, A. Boutin, J. Hackett, D. Stroud, G. F.Mayhew, D.J. Rose, S. Zhou, D. C. Schwartz, N. T. Perna, H. L T. Mobley, M. S. Donnenberg, F. R. Blattner. (2002), Extensive mosaic structure revealed by the complete genome sequence of uropathogenic Escherichia coli. Proc. Natl. Acad. Sci. U S A. 99: 17020-17024.

Williams, P.H. (1979), Novel iron uptake system specified by ColV plasmid: an important component in the virulence of invasive strains of Escherichia coli. Infect. Immun. 26:925-932.

Received: May 29, 2006; Revised: January 11, 2007; Accepted: December 28, 2007. 